\title{
School Library Perspectives from Asia: Trends, Innovations and Challenges in Singapore, Hong Kong and Japan
}

\author{
Chin Ee Loh \\ chinee.loh@nie.edu.sg \\ Nanyang Technological University, Singapore
}

\author{
Annie Tam \\ atam@isf.edu.hk \\ The Independent Schools Foundation Academy, Hong Kong
}

\section{Daisuke Okada}

yansenmu@gmail.com

Soai University, Japan

Keywords: Trends, innovations, school library, Singapore, Hong Kong, Japan

\begin{abstract}
In this global, multicultural world requiring greater levels of literacy, independent learning and collaboration, the school library as a learning hub needs to meet the needs of $21^{\text {st }}$ century students. However, more information about how different countries' school library policies and practices is required for nations to learn from each other. This professional panel brings together three presenters from Singapore, Hong Kong and Japan to engage with the issue of what counts as a future-ready library in their own contexts of reading and learning. Each presenter will focus on the current trends, challenges and innovations in their own contexts, with particular focus on national policies, practices and librarian education. Significant parallels and differences across the different systems will be discussed. Implications for developing future-ready school libraries and librarians at national level will be discussed.
\end{abstract}

\section{Introduction}

In this global, multicultural world of the Fourth Industrial Revolution (Schwab, 2017), the shift towards disruptive technologies, artificial intelligence means that students today need ever higher levels of literacy to engage in twenty-first century consumption and work. There is also a greater need for students to become independent learners who are able to negotiate and manage almost unlimited access to information in their everyday lives. Students need to become lifelong learners who continuously expand their reading repertoires to learn new things for living, work and participation in the larger community (Kirsch et al., 2001). In this context, the school library's role as a learning hub (Canadian Library Association, 2014) is particularly crucial to development future-ready readers and learners. In addition, because of the proximity of the school library compared to public libraries, students from low-SES 
backgrounds are more likely to use the school library (Loh, 2018). This means that school libraries are well-placed to provide resources to encourage independent reading and learning, compared to public libraries, which which may be differently accessed and utilized by students from different socioeconomic backgrounds (Neuman \& Celano, 2012).

Despite the recognition of the importance of the school library for developing future-ready learning, there is little information about school library policies in different parts of the world. The International Association of School Librarianship's Window on the World School Library profiles provide brief overviews but may lack detail, depending on the source of information in each country (International Association of School Libraries, n.d.). Moreover, as academics and practitioners advocating for the development of school libraries in their individual country contexts, the authors of this paper realised that comparative data across similar policy contexts will help policymakers and academics better understand school libraries and their needs, and to provide insight for moving ahead.

This comparative paper provides an overview of trends, innovations and challenges in Singapore, Hong Kong and Japan. These three countries are all developed countries in Asia with strong emphasis on educational system, and as such, provide comparable contexts for understanding school library and librarianship development. We hope to provide an example of how a comparative analysis of school library and librarianship policies and practice can engender action within and across each context.

\section{Comparisons Across Singapore, Hong Kong and Japan}

\section{Singapore}

The Singapore education system is well-regarded as an effective school system, producing top scorers on international assessments such as PISA and PIRLS. The educational system is largely centrally controlled and the Ministry of Education (MOE) plays a significant role in shaping policy, curriculum and instructional approaches. All government school teachers are trained at the National Institute of Education (NIE), and the synergy between MOE and NIE ensures alignment between teacher training, research and national aims (OECD, 2010). In addition to government schools, there are government-aided schools, autonomous schools, independent and international schools. In total, there are 185 primary schools, 143 secondary schools, 16 mixed level schools and 15 junior colleges in Singapore (Ministry of Education, 2018). In the last few years, the MOE has sought to focus more on joy in learning and providing equitable access to education (Ong, 2018).

Currently, it is compulsory for all government schools (primary/secondary/ junior college) to have school libraries and there are guidelines for minimum size and provision of facilities. At MOE, the Media Resource Library (MRL) team under the English Language and Literature unit at the Curriculum Planning and Development Division oversees school libraries. The MRL handbook (2013) states that each school library should be under the purview of a team comprising a Head of Department, one teacher who serves as a library coordinator and a few subject-teachers. The Vice-Principal should serve as the advisor of the MRL team. However, few schools follow this model. Instead, most school libraries are managed by library coordinators or full-time (often English) teachers who are tasked with the additional role of managing the library. Unlike the government schools, international schools in Singapore are more likely to be staffed by professional librarians. A survey of 13 schools showed that schools staffed with librarians were better used and had better collections and programming (Loh \& Sundaray, 2019). All school libraries are supported by Civica, a system provider. A library assistant or officer helps with the day-to-day operations of the school library.

International Association of School Librarianship

https://iasl-online.org 
In terms of training and support, there are few training options for librarians or library technicians in Singapore. The Wee Kim Wee School of Communication and Information offers library and information science courses but do not cater to school librarians. There is no demand for such a course since the school librarians are not required under national law. The Library Association of Singapore periodically offer professional development courses for library technicians but these courses may not be regular. In comparison, most international schools are staffed by professional librarians (often trained overseas or through distance learning courses). International schools have a well-connected network and support system with their International School Libraries Network (ISLN) in Singapore.

Currently, the Media Resource Library team at MOE is placing more emphasis on reading. There is concerted effort to improve funding for books and professional development for library coordinators. In the last five years, MOE has increased development opportunities for library coordinators. Starting from 2016, MOE co-organised, with NIE and the National Library Board (NLB), an annual workshop for primary and secondary school library coordinators. To date, more than 200 library coordinators have attended these full day sessions. An annual Reading Symposium is organised to encourage networking and sharing of best practices. Since 2018, NIE, with the support of MOE and the Academy of Singapore Teachers (AST) has started offering professional development courses for library coordinators and librarians.

Sustained research on school libraries, largely under the Building a Reading Culture grant, has highlighted the need to improve school libraries and provided evidence-based data for systematic knowledge building among policymakers, principals and library coordinators (Loh et. al., 2017). Key factors for the relative success in raising school library awareness in Singapore include the following strategies over the last five years: (1) deliberate research communication to the public, government and educators; (2) development of localized framework and resources; and (3) focus on creating evidence-based professional development courses. Currently, MOE is committed to rethinking the design of library collection, space and programming. Design thinking is being used to rethink three future-ready school libraries, and a design protocol and improved guidelines will result from these projects. Many schools are also looking at renovating and revitalizing their school libraries.

While these are exciting times for school libraries in Singapore, challenges remain. Since school libraries are managed by teachers who serve as library coordinators (rather than professional librarians), it will be a challenge for them to find time outside their full teaching load to maintain and improve their school libraries and attend professional development courses. MOE and the principal's support is vital for real change to happen. At present, it may not be easy for schools to secure the funding required if they wish to renovate and refresh their library space and collection. Finally, although the knowledge base is increasing, more practical knowledge and know-how, particularly in the areas of developing the book collection, using technology meaningfully and information literacy training, is required.

\section{Hong Kong}

The Hong Kong Government has been providing 9-year free and universal basic education (6 years of primary education and 3 years of junior secondary education) through public sector primary and secondary schools (including government schools, aided schools and caput schools) since 1978 (GovHK, 2019). To demonstrate the Government's commitment to the nurturing and education of our next generation, free education is extended to include senior secondary education provided by public sector secondary schools starting from the 2008/09 school year. The beneficiaries include students pursuing Secondary 4 to Secondary 7 under the current secondary school structure (meaning 13 years of free

International Association of School Librarianship

https://iasl-online.org 
education) and students pursuing Senior Secondary 1 to Senior Secondary 3 under the New Senior Secondary structure to be introduced from the 2009/10 school year (meaning 12 years of free education). In the 2018/19 school year, there are 587 primary schools, 506 secondary day schools and 61 special schools.Kindergarten education in Hong Kong is for children from three to six years old. Local non-profit-making kindergartens joining the kindergarten education scheme are provided with direct government subsidy.

Public sector schools form the majority in the 6-year primary and 6-year secondary basic education. These consist of government schools operated directly by the Government and aided schools that are generally run by religious or charitable organisations, fully subvented by the Government and managed by incorporated management committees or school management committees. In addition, there are Direct Subsidy Scheme (DSS) schools, which can charge school fees and receive government subvention based on enrolment, and self-financed private schools providing alternatives to parents.

The Government is committed to developing a vibrant international school sector mainly to meet the demand for international school places from non-local families living in Hong Kong and families coming to Hong Kong for work or investment. In the 2018/19 school year, there are 54 international schools in Hong Kong, which generally operate on a self-financing basis and offer different non-local curricula.

All government schools have school libraries. There are guidelines from the Education Development Bureau (EDB) for school libraries' book, furniture and equipment purchasing procedures (Education Bureau, 2017). There are also guidelines from EDB about the role of a teacher librarian in the New Senior Secondary (NSS) Curriculum. All government schools' primary and secondary teachers with 2 years of teaching experience are eligible to apply for the post of teacher librarian. After teacher librarians are appointed, they are required to study for the course of Diploma in Teacher Librarianship (HKUSpace, 2019), which is designed for serving and newly appointed teacher librarians.

There is strong support for teaching librarian training in Hong Kong. The course Diploma in Teacher Librarianship provides training for the serving or newly appointed teacher librarians. The programme is under the monitorship of Education Bureau and jointly organized by HKUSPACE. The University of Hong Kong offers Master of Science in Library and Information Management which teacher librarians can apply. EDB also provides short PD courses for teacher librarians to join during school hours. In addition, the Hong Kong Library Association (HKLA, n.d.) has a School Libraries Liaison Officer. The international schools have a well-connected network with the Association of Librarians in English Speaking Schools (ALESS, n.d.).

A positive development in $\mathrm{HK}$ is increased attention to the role of the school library to support reading. In Booklet 6B: Reading to Learn: Towards Reading across the Curriculum of the Secondary Education Curriculum Guide (Education Bureau, 2017), various strategies for promoting reading and the role of a teacher librarian at school are provided.

- Starting from the school year of 2018/19, revival of school book funding programme to primary and secondary schools (Cheung, 2018).

- Under the Curriuclum development of EDB, Reading to Learn webpage provides updated information of promotion of reading.

- Framework of information literacy for Hong Kong students was developed, which gave teacher librarians a clear guideline for information literacy instruction (Education Bureau, 2017). 
- Regular seminars and training are organized by EDB so that teacher librarians can share their best practices with their peers.

- Hong Kong Teacher-Librarians Association formed a WhatsApp group to give support and share their best practices with their peers.

- International Association of School Librarianship in collaboration with Hong Kong Teacher Librarians' Association established the Teacher Librarian Excellent Achievement Award to honor the teacher librarians for their contribution towards the development of Hong Kong school libraries and services biennially.

Some challenges that remain include the general lack of understanding about the role of teacher librarians. Some school administration and subject teachers' lack of general understanding about the important role of the school library and teacher librarian in promoting the schools' reading culture. Thus, some teacher librarians are assigned with other teaching duties such as being a class teacher, a subject teacher or a substitute teacher. As a result, teacher librarian does not have enough time to run the library and collaborate with subject teachers. In some cases, the teacher librarian is even overloaded to substitute lessons. Moreover, library lessons are not scheduled in the timetable in most Secondary schools and teacher librarians have found it hard to collaborate subject teachers. Finally, since there is not a specific appraisal system to cater for the special job duties of a teacher librarian, they are often not promoted to senior ranking posts.

\section{Japan}

In Japan, the education system is unified. In most cases, students attend local schools until the ninth grade (15 years old). Students take a first entrance examination when they are 15 years old and are allocated schools based on their ability and choice from 10th to 12 th grade. The second test is when students enter universities. There is a strong emphasis in Japan on good grades as getting into a "good" university leads to working in a "good" company. Many high school students do their best to study for the university examinations. However, many Japanese university students learn little because many Japanese companies do not care about what students have studied at university. In other words, in Japan, inquiry-based learning has not been required for many years.

The School Library Law article III requires all types of schools (elementary / high / special needs/ government / private) must have a school library. The term "school library" is not defined in the article. The Japanese school library is staffed by two kinds of workers: "teacher-librarian" and "school librarian." Schools with more than 12 classes must have a certified teacher-librarian (Article V) who is trained at the university. However, since the law does not require teacher-librarians to work solely in school libraries, almost all teacher-librarians are also classroom teachers. Teacher-librarians spend approximately 2.2 hours a week in the school library. About $50 \%$ of Japanese schools are staffed by teacher-librarians. The other $50 \%$ of Japanese schools are staffed with school librarians who do not have a teacher position. They do not have teaching licences but often possess qualifications in library skills. Many have the public library librarian certificates. However, many of them are temporary workers, and have a low pay of USD8 an hour.

About 20 years ago, when the teacher-librarian role was made compulsory, the long-employed school librarians opposed the move. The general claim is this: Schools with teacher-librarians do not hire school librarians. This may result in the minimal development of the school library. Their allegations were generally true and they were never fired, but after their retirement, most of the new librarians were part-timers. However, the situation has improved: 10 years ago, $30 \%$ of primary schools had school

International Association of School Librarianship

https://iasl-online.org 
librarians. It is now 50\%. It may be ideal for schools to have teacher-librarians and school librarians to work together to maximize students' learning through the school library, though it may be a practical impossibility in most situations.

There are various opportunities for training and professional development. Over 200 universities have the teacher-librarian programme, but the programme is a sub-major and not the major. If you a teacher licence holder in Japan, you can get the teacher librarian certification by attending courses over a period of 15 weeks. Some programmes are held as summer courses by local normal universities and tuition is free. There are two distance course held by private universities and the fee is USD 3,000 for these courses. A school librarian model curriculum containing 10 lectures was started in 2018, but few have completed the course. Some inservice school librarians have the public librarian certification and some have no certification. Typically, local boards of education hold seminars once a year, and more enthusiastic local boards may conduct monthly courses. In addition, the National School Library Association (SLA) may hold limited courses for inservice school librarians in Tokyo. SLA also organizes a conference every two years, typically attended by about 3,000 participants. School librarians have another association, and about 150 people attend their meetings.

The Ministry of Education, Culture, Sports, Science and Technology (MEXT) have provided some guidelines, which include the following.

the national curriculum for elementary or high school requires some lessons on school libraries to be held in school;

- the number of materials on school libraries by the number of their classrooms; and curriculum for future teacher librarians and school librarians.

Unfortunately, the guidelines are not always effectively implemented. Japan is a test-based country, and as inquiry-based learning skills are perceived not to help with admission to upper schools, many teachers are reluctant to teach inquiry-based skills. The central government has put aside one billion USD for materials and one billion USD for the salary of school librarian over five years. However, as Japan is a decentralization country, local governments often use the money for other purposes.

Challenges for the Japan school context includes lack of funding for school libraries and low salaries for school librarians. Many teachers are unaware of the usefulness of the school library and librarian because they do not have experience in teaching in the school library or collaborating with school librarians. Teacher-librarians are often the only teachers who have experienced inquiry-based learning at university level, which is important for preparing students for future learning. Even excellent librarians have few opportunities to step up and may burn up due to overwork. However, the employers treat the librarian's job lightly because there are many candidates. Greater awareness of the role of school libraries and librarians in preparing teachers for the future is required.

\section{Discussion}

The comparisons of Singapore, Hong Kong and Japan show that these countries are forward-looking in establishing the need for a school library. However, challenges remain.

Firstly, the invisibility of the school librarian's work remains a problem across the three countries. Hochman (2016) notes that nostalgic stereotypes of librarians whose perceived sole job is to keep students quiet obscure the real and necessary work of school librarians (such as curation of books, lesson planning and collaboration with teachers), which is often behind the scenes (Radlick \& Stefk-Mabry, 2018). This invisibility to policymakers, administrators and teachers means that librarians or teachers working in

International Association of School Librarianship

https://iasl-online.org 
school libraries need to advocate outside the school library. However, it is difficult for a single librarian or teacher to persuade the entire school, particularly when little is known about his or her work. Where principals are supportive, school librarians are more likely to get the support they need (Oberg, Hay \& Henri, 2000). In Japan, the new MEXT policy document states that the director of the school library is the principal and in Singapore, the MRL guidelines state that the Vice-Principal should oversee the school library. However, in reality, the support of the principals are school-dependent. In Japan, the teacher-librarian (rather than a school librarian) is the ideal advocate for the school library, but this is not realized in many schools due to a lack of understanding about their roles and possible contribution to curriculum and learning. Evidence-based research (Todd, 2015) in Singapore and deliberate engagement with policymakers, teachers and the National Library has led to increased awareness of the role of school libraries, but sustained effort at improving school libraries and communicating change is required to educate policymakers, principals, educators and members of the public about the important role of school libraries.

Secondly, all three countries have school library guidelines. However, guidelines are only meaningful if supported with formal structures, training and resources for implementation. Hong Kong provides an example of how an ecology of support and resources support the government's focus on reading. Other than formal training for librarians, active school library societies provide ongoing support and forum for school librarians. However, even in Hong Kong, the lack of time set aside for a library curriculum within school hours may prevent library staff from successfully implementing desired improvements and programmes. The ability of the library teacher to collaborate with other subject-teachers to optimize learning and to teach inquiry is limited when library teachers do not have sufficient time to teach or collaborate with other subject-teachers. Across the three countries, it may be that educators themselves do not yet understand the importance of librarians in teaching information literacy, vital in a time of "fake news" and ceaseless information. Creating more awareness about information literacy and how librarians are prepared for teaching information literacy may be one way to demonstrate the importance of setting time aside for those involved in library work to teach these key skills.

Finally, how does one decide if the school libraries in each country are effective or not? Absent across the discussions of school libraries are discussions of how school libraries are evaluated to determine if they actually support and enhance learning. In Japan, teacher-librarians are trained to provide inquiry-based learning but due to the lack of awareness about how teacher-librarians are actually equipped to teach students inquiry skills essential for future learning, schools do not give teacher-librarians recognition or time required to do the job effectively. In Singapore, the traditional association of the library with reading only leads to neglect of the school library as a place for knowledge building. Re-configuring the role of the school library to support future learning requires re-conceptualizing the role and function of the library. Having clear objectives for what a future-ready library should look like and evaluation criteria will allow these systems to improve their school libraries for learning (Hay, 2009). Evaluative criteria will also provide standards for schools to use design-based approaches to improve their school libraries for their particular student profile.

Certainly, a comparative approach to school libraries will allow countries to learn from each other in terms of library policy and practice. Regional exchanges such as the IASL Association of Southeast Asian countries (ASEAN) annual regional workshop provide avenues for sharing and discussion. However, more detailed and deliberate comparisons across contexts will allow advocates of library work to speak to policymakers, educators and members of the public in a concerted manner. We hope this comparison provides a starting point.

International Association of School Librarianship

https://iasl-online.org 


\section{REFERENCES}

ALESS. (n.d.) The Association of Librarians in English Speaking Schools (Hong Kong). Retrieved from https://sites.google.com/view/alesshk.

Canadian Library Association. (2014). Leading learning: standards of practice for school library learning commons in Canada 2014. Canada: Canadian Library Association.

Cheung, T. (April 17, 2018). HK government launches HK\$48 million school book funding programme. Retrieved from https://www.edb.gov.hk/en/curriculum-development/renewal/guides_SECG.html.

Education Bureau. (2017). Information literacy for Hong Kong students. Retrieved from https://www. edb.gov.hk/en/edu-system/primary-secondary/applicable-to-primary-secondary/it-in-edu/informat ion-literacy/il-index.html.

Education Bureau. (2017). School library services - information kiosk for school libraries. Retrieved from https://www.edb.gov.hk/en/curriculum-development/resource-support/sch-lib-services/ information-kiosk-for-sch-lib/index.html

Education Bureau (2017) Ongoing renewal of the school curriculum. Retrieved from https://www.edb .gov.hk/en/curriculum-development/renewal/guides_SECG.html.

Gov, HK. (2019). Hong Kong: The facts (education). Retrieved from https://www.gov.hk/en/about/a bouthk/factsh eets/docs/education.pdf.

Hay, L. \& Foley, C. (2009). School libraries building capacity for student learning in 21C. SCAN 28(2), $17-26$.

HKLA. (n.d.) Hong Kong Library Association. Retrieved from https://hkla.org/.

HKUspace. (2019). Library and information studies. Retrieved from https://hkuspace.hku.hk/pr og/dip-in-teacher-librarianship.

Hochman, J. (2016). School library nostalgias. Curriculum Inquiry, 46(2), 132-147.

International Association of School Libraries. (n.d.). Window on the world of school libraries: school library country profiles. Retrieved from https://www.iasl-online.org/WOW.

Kirsch, I., de Jong, J., Lafontaine, D., McQueen, J., Mendelovits, J., \& Monseur, C. (2002). Reading for change: performance and engagement across countries. Paris: Organisation for Economic Co-operation and Development.

Loh, C. E. (2018). Reading, poverty, and what schools can('t) do about it. Retrieved from https://www. youtube.com/watch?v=awv6Anu3qIM\&list=PLtUdDWXmPgvoMATYbZcM_DwPV0lpGod19 \&inde $=2 \& \mathrm{t}=0 \mathrm{~s}$. 
Loh, C. E. \& Sundaray, S. (2019). Technical report: school library perspectives survey report 2018. Singapore: Office of Education Research, National Institute of Education.

Loh, CE, Ellis, M., Paculdar, A. \& Wan, ZH. (2017). Building a successful reading culture through the school library: a case study from Singapore. IFLA Journal 43(4), 335-347.

Ministry of Education (2018). Education statistics digest 2018. Singapore: Ministry of Education.

Ministry of Education (2013). Media resource library handbook. Singapore: Ministry of Education.

Neuman, S. B., and Celano, D. (2012). Giving our children a fighting chance: poverty, literacy and the development of information capital. NY: Teachers College Press.

Oberg, D., Hay, L. \& Henri, J. (2000). The role of the principal in an information literate school community: design and administration of an international research project. School Library Media Research 3,1-24.

OECD. (2010). Singapore: rapid improvement followed by strong performance. France: OECD.

Ong, Y. K. (September 28, 2018) Opening address by Mr Ong Ye Kung for Education, at the school's work plan seminar. Retrieved from https:/www.moe.gov.sg/news/speeches/opening-addressby-mr-ong-ye-kung--minister-for-education--at-the-schools-work-plan-seminar.

Schwab, K. (2017). The Fourth Industrial Revolution. NY: Random House.

Todd, R. J. (2015). Evidence-based practice and school libraries: interconnections of evidence, advocacy and actions. Knowledge Quest 43(3), 8-14.

Radlick, M., \& Stefk-Mabry, J. (2018, April 16-20, 2018). Finally - convincing evidence for the impact of school librarians. Paper presented at the American Educational Research Association Conference. New York.

\section{Biographies}

Chin Ee Loh is an Assistant Professor in the English Language and Literature Academic Group at the National Institute of Education, Nanyang Technological University, Singapore. Her research focuses on literature and literacy education, particularly on reading, design and school libraries (project website: https://www.readingculturesg.org/).

Annie Tam is Master Teacher and Head Librarian of Secondary, The Independent Schools Foundation Academy, Hong Kong. She worked in schools and libraries in Hong Kong and Singapore for over 20 years.

Daisuke Okada is a Lecturer at Soai University, Japan. He served as a teacher librarian at a private junior high school. His research interests include training for teacher librarians. 